\title{
Pesquisar é um ato de coragem!
}

Gerar a idéia já é um dom de apenas alguns; pensar na hipótese e executar o projeto é, sim, um ato de coragem.

No Brasil, a pesquisa dá ainda os seus primeiros passos. As dificuldades impostas pela falta de recursos algumas vezes levam os investigadores a desanimarem.

Muitos, entretanto, têm aceito estes desafios e, mesmo lutando contra diversas situações difíceis, estão expondo seus trabalhos ao resto do mundo.

Este ano, no Congresso da American Thoracic Society (ATS), dos 5.354 estudos apresentados, $91(0,16 \%)$ foram de brasileiros. Isto representa uma pequena parcela da pesquisa internacional, mas ainda assim é pesquisa, pesquisa de valor. A pesquisa brasileira de todas as áreas é cerca de $0,2 \%$ da pesquisa mundial. Portanto, nós, pneumologistas, estamos contribuindo com nossa parcela. A verdade é que estivemos lá e queremos estar em outros lugares!

Certamente todos nós ficamos orgulhosos por cada poster ou apresentação de slides vindos do Brasil (e até um conferencista brasileiro estava lá, fantástico!)

Críticas sempre ocorrerão, mas e daí? Só se expõe quem tem coragem. E temos!

Os congressos internacionais atualmente têm servido não apenas para que possamos buscar os conhecimentos de ponta, mas também para trocarmos essas experiências com pesquisadores de outros centros. A produção científica dos brasileiros tem crescido visivelmente. E o mais importante é que somos capazes de produzir com qualidade.

Estamos ainda tímidos nesta jornada, mas as etapas estão sendo vencidas.

Reunimo-nos em San Diego com emoção (para quem ainda não sabe, os brasileiros compartilharam um jantar no Marriot de San Diego), porque finalmente começamos a representar mais do que nós mesmos individualmente, a Sociedade que nos integra.

A SBPT estava conosco em San Diego e o J ornal de Pneumologia, ao publicar neste número os resumos dos trabalhos lá apresentados, ratifica a importância que a pesquisa no Brasil tem assumido.

Está pois de parabéns a SBPT, estão de parabéns todos aqueles que enfrentaram os desafios da pesquisa e tiveram coragem de ficar expostos aos seus pares e a muitos outros e estão de parabéns aqueles que aqui ficaram enfrentando as dores e dispnéias dos nossos pacientes, tornando possível a ida de tantos.

J USSARA FITERMAN MOLINARI

Doutora em Pneumologia pela UFRGS, Professora A djunta da Divisão de Pneumologia da PUCRS, Presidente da Comissão de Assuntos Internacionais da SBPT 